Research Paper

\title{
Photoactivation Studies of Zinc Porphyrin-Myoglobin System and Its Ap- plication for light-Chemical Energy Conversion
}

\section{Chin-Hao Chang ${ }^{1}$, Yi-Ting Hu', Chen-Fu Lo², Liyang Luo ${ }^{3}$, Hung-Ming Lin ${ }^{1}$, Cheng-Hsiang Chang', Ching-Yao Lin ${ }^{2 凶}$, Eric Wei-Guang Diau ${ }^{3 凶}$, and Tung-Kung Wu ${ }^{1 凶}$}

1. Department of Biological Science and Technology, National Chiao Tung University, 30068, Hsin-Chu, Taiwan, Republic of China

2. Department of Applied Chemistry, National Chi Nan University, Puli, Nantou County, Taiwan, Republic of China

3. Department of Applied Chemistry and Institute of Molecular Science, National Chiao Tung University, Hsin-Chu, Taiwan, Republic of China

Corresponding author: T. K. Wu, Department of Biological Science and Technology, National Chiao Tung University, 30068, Hsin-Chu, Taiwan, Republic of China. Tel: +886-3-5729287 Fax: +886-3-5725700 E-mail: tkwmll@mail.nctu.edu.tw or C. Y. Lin, Department of Applied Chemistry, National Chi Nan University, Puli, Nantou County, Taiwan, Republic of China. Fax: +886-49-2917956 Tel: +886-49-2910960-4152 E-mail: cyl@mail.ncnu.edu.tw or Eric W. G. Diau, Department of Applied Chemistry and Institute of Molecular Science, National Chiao Tung University, Hsin-Chu, Taiwan, Republic of China. Fax: +886-3-5723764 Tel: +886-3-5712121-31524 E-mail: diau@mail.nctu.edu.tw

(c) Ivyspring International Publisher. This is an open-access article distributed under the terms of the Creative Commons License (http://creativecommons.org/ licenses/by-nc-nd/3.0/). Reproduction is permitted for personal, noncommercial use, provided that the article is in whole, unmodified, and properly cited.

Received: 2011.05.03; Accepted: 2011.09.07; Published: 2011.10.27

\begin{abstract}
An artificial zinc porphyrin-myoglobin-based photo-chemical energy conversion system, consisting of $\mathrm{ZnPP}-\mathrm{Mb}$ or $\mathrm{ZnPE} \mathrm{E}_{1}-\mathrm{Mb}$ as a photosensitizer, $\mathrm{NADP}^{+}$as an electron acceptor, and triethanolamine as an electron donor, has been constructed to mimic photosystem I. The photoirradiated product is able to reduce a single-electron acceptor protein cytochrome $c$, but cannot catalyze the two-electron reduction of acetaldehyde by alcohol dehydrogenase, thus demonstrating a single electron transfer mechanism. Furthermore, the artificial system can bifunctionally promote oxidoredox reactions, depending on the presence or absence of a sacrificial electron donor, thus suggesting its potential application in electrochemical regeneration steps involved in chemical transformation and/or energy conversion.
\end{abstract}

Key words: photoelectrochemical energy conversion, zinc protoporphyrin, myoglobin, oxidoredox reaction, biosensitizer

\section{Introduction}

In biological photosynthesis, light energy is converted into electrochemical energy, stored as adenosine triphosphate (ATP) and nicotinamide adenine dinucleotide phosphate (NADPH), and subsequently used for carbohydrates and other compound formation. It has been known that porphyrins and proteins with redox activity are key factors of photosynthesis. Artificial analogues of these processes are being investigated as methods for electricity [1-3], chemical energy [4], and hydrogen production [5,6]. For example, porphyrins and related porphyrinoids have been shown to be promising candidates for the fabrication of porphyrin-based dye sensitized solar cells (DSSCs) and organic solar cells, based on the intrinsic properties of the molecules including their vital roles in photosynthesis, intense absorption in the visible region, and diverse structural plasticities for light harvest [7-12]. Recently, Yeh, Diau, and Grätzel 
et al. reported a porphyrin-based DSSC, YD2, with an overall energy conversion efficiency of $11 \%$, comparable to the state-of-the-art ruthenium-polypyridyl-based ones [13].

In parallel, many achievements on the study of intermolecular photoinduced electron transfer reactions have been constructed by replacing heme with zinc-protoporphyrins (ZnPPs), due to the longer lifetime of the excited triplet state compared with other metalloporphyrins and its function as strong reductants [14-18]. Hu et al. have constructed a myoglobin-based donor-sensitizer-acceptor triad to aid in the understanding of the long-lived charge-separated states and the regulation of the electron transfer pathway [19]. Moreover, reconstitution of apomyoglobin (apoMb) or human serum albumin (HSA) with zinc-protoporphyrin has greatly expanded protein function from oxygen storage or transport to that of a new functionalized enzyme with electron transfer properties and chemical reactivity [20-22]. These results indicated that the protein's environment can control and organize the coordination of prosthetic groups, prevent quenching aggregate, and prolong the lifetime of charge separation [19,23-32].

In light of the important biomimetic application of the photosystems, we present a zinc porphyrin-myoglobin-based photo-chemical energy conversion system which, upon photoirradiation, can catalyze the reduction of $\mathrm{NADP}^{+}$to NADPH. Two dif-

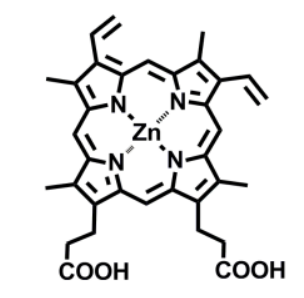

Zn(II) Protoporphyrin (ZnPP)

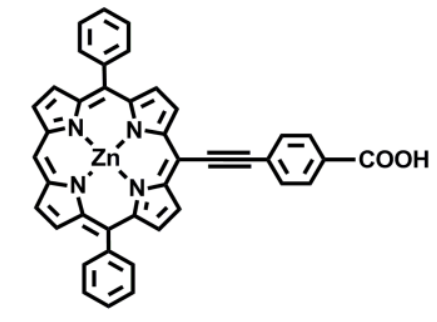

5-(4-carboxy-phenylethynyl)-10,20biphenylporphinato zinc(II) $\left(\mathrm{ZnPE}_{1}\right)$ ferent porphyrin derivatives, $\mathrm{ZnPP}$ and 5-(4-carboxyphenylethynyl)-10,20-biphenyl porphinato zinc (II) $\left(\mathrm{ZnPE}_{1}\right)$ (Fig. 1), were independently reconstituted into apoMb to form $\mathrm{ZnPP}-\mathrm{Mb}$ or $\mathrm{ZnPE} 1-\mathrm{Mb}$ complexes and were compared for their light to chemical energy conversion efficiency. The experimental results showed that reconstitution of $\mathrm{ZnPP}$ or $\mathrm{ZnPE}_{1}$ into an apoMb protein pocket can prevent the quenching aggregation and extend the lifetime of charge separation. The substitution of $\mathrm{ZnPP}$ with $\mathrm{ZnPE}_{1}$ can improve up to a two-fold the efficiency of the light to chemical energy conversion. The $\mathrm{ZnPP}-\mathrm{Mb}$ or $\mathrm{ZnPE}_{1}-\mathrm{Mb}$ system carried out a step-to-step one electron transfer mechanism upon photo-induced charge transfer, as demonstrated by the catalysis of a single-electron reduction of ferricytochrome $c$ to ferrocytochrome $c$ by cytochrome $c$. Furthermore, the artificial system exhibited a bifunctionally promote redox reaction dependent on the presence or absence of a sacrificial electron donor. This study is the first report to describe the reconstituted $\mathrm{ZnPP}-\mathrm{Mb} / \mathrm{ZnPE}_{1}-\mathrm{Mb}$ system as a bifunctional photo-induced oxidoredox system to convert solar energy into chemical energy. Therefore, the construction of such a photosystem would in principle serve as a self-regenerative photoelectrochemical cell and could be applied to electrochemical regeneration steps involved in chemical transformation and/or energy conversion as well as for sensor applications.

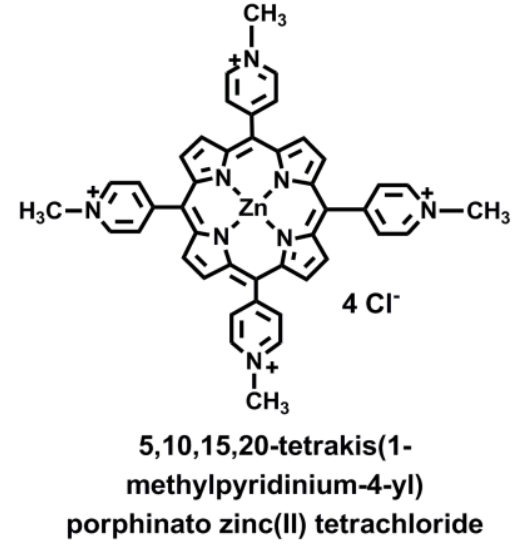

(ZnTMPyP4 ${ }^{+}$)

Fig. I. Structure of zinc protoporphyrin (ZnPP), 5-(4-carboxy-phenylethynyl)-10,20-biphenylporphinato zinc (II) (ZnPE $\left.\right|_{1}$ ), and 5,10,15,20-tetrakis(I-methylpyridinium-4-yl) porphinatozinc(II) tetrachloride $\left(\mathrm{ZnTMPyP}{ }^{4+}\right)$.

\section{Results and discussion}

\section{Steady-state, picosecond fluorescence, and anisotropy dynamics of $\mathrm{ZnPE}_{1}-\mathrm{Mb}$}

The dynamics of electronic and orientational relaxations of the $\mathrm{ZnPP}-\mathrm{Mb}$ complex in aqueous solu- tion have been studied using the time-correlated single-photon counting (TCSPC) technique [31]. Measurement of UV-vis spectra of $\mathrm{ZnPE}_{1}$ in THF and $\mathrm{ZnPE}_{1}-\mathrm{Mb}$ in $\mathrm{KPi}$ solution showed similar red-shift of Soret and Q bands from 439 to $443 \mathrm{~nm}$ and 567/615 to $576 / 628 \mathrm{~nm}$, respectively (Supplementary Material: Figure S1). Time-resolved fluorescence anisotropy 
decays of the system showed significant change in rotational correlation period from $0.25 \mathrm{~ns}\left(\mathrm{ZnPE}_{1}\right.$ in $\mathrm{THF})$ to $\sim 10 \mathrm{~ns}\left(\mathrm{ZnPE}_{1}-\mathrm{Mb}\right.$ in $\left.\mathrm{KPi}\right)$, giving the evidence for the successful construction of $\mathrm{ZnPE}_{1}-\mathrm{Mb}$ complexes (Fig. 2A) in aqueous solution. Picosecond fluorescence transient of $\mathrm{ZnPE}_{1}-\mathrm{Mb}$ in $\mathrm{KPi}$ at $295 \mathrm{~K}$, with excitation at $\lambda_{\mathrm{ex}}=435 \mathrm{~nm}$ and emission at $\lambda_{\mathrm{em}}=$ $630 \mathrm{~nm}$, showed a biexponential decay feature with two time coefficients: $\tau_{1}=0.6 \mathrm{~ns}$ and $\tau_{2}=2.5 \mathrm{~ns}$ (Fig. 2B).

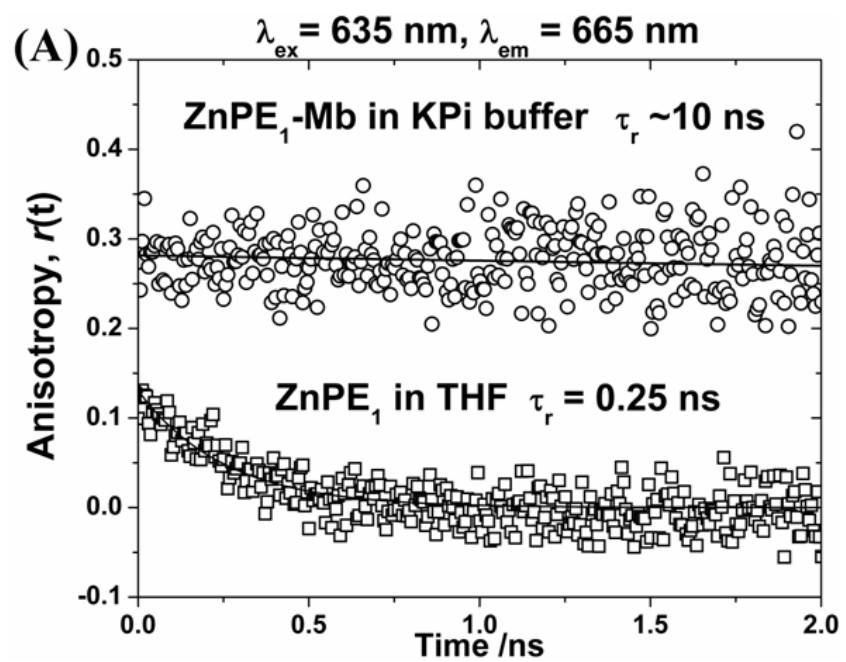

(B)

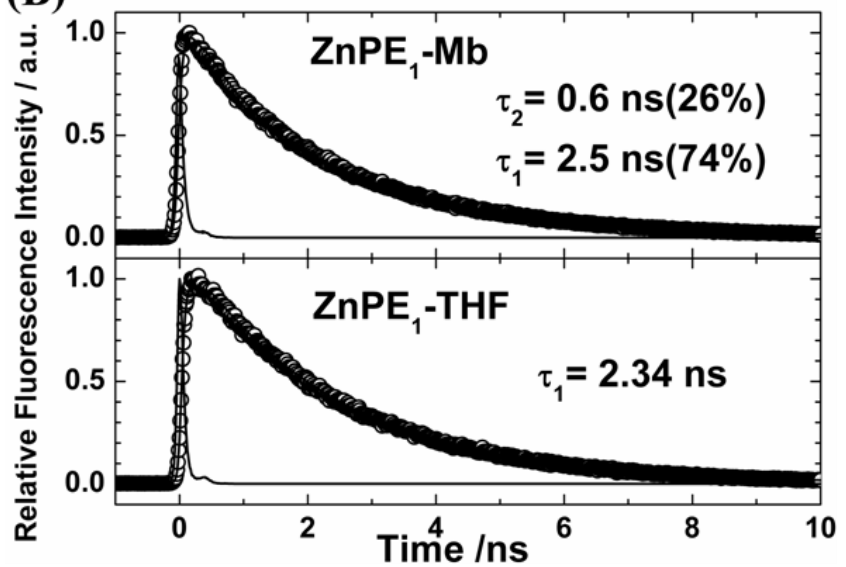

Fig. 2. (A) Picosecond fluorescence anisotropy of $\mathrm{ZnPE}_{1}$ in THF (squares) and encapsulated within apomyoglobin in buffer solution (circles) obtained at $\lambda_{\mathrm{em}}=655 \mathrm{~nm}$ with excitation at $\lambda_{\text {ex }}=635 \mathrm{~nm}$. (B) Picosecond fluorescence transient of $\mathrm{ZnPE}_{1}-\mathrm{Mb}$ complex in $\mathrm{KPi}$ with $\lambda_{\text {ex }}=435 \mathrm{~nm}$ and $\lambda_{\mathrm{em}}=630 \mathrm{~nm}$. For $\mathrm{ZnPE}_{1}$ in THF, the $\lambda_{\mathrm{ex}}=435 \mathrm{~nm}$ and $\lambda_{\mathrm{em}}=623 \mathrm{~nm}$.

Because the lifetime of $\mathrm{ZnPE}_{1}$ in THF is $2.34 \mathrm{~ns}$ due to the $S_{1}-T_{1}$ intersystem crossing (ISC) of the zinc porphyrin, the slow decay component of the
$\mathrm{ZnPE}_{1}-\mathrm{Mb}$ transient $\left(\tau_{2}=2.5 \mathrm{~ns}\right)$ is reasonably assigned to the isolated $\mathrm{ZnPE}_{1}$ molecules inside the heme pocket of apoMb $[29,31]$. We noticed that porphyrin molecules form aggregates in KPi buffer, and this is the case for both $\mathrm{ZnPP}$ and $\mathrm{ZnPE}_{1}$ [31]. Intermolecular energy transfer would become very efficient in porphyrin aggregates [32]. As a result, the fast-decay component of the $\mathrm{ZnPE} 1-\mathrm{Mb}$ transient $\left(\tau_{1}=\right.$ $0.6 \mathrm{~ns}$ ) is assigned to the $\mathrm{ZnPE}_{1}$ aggregates outside the active site of the apoMb in buffer solution $[3,31]$.

\section{Assembly of artificial photosynthetic system and measurement of light-chemical energy conversion efficiency}

The artificial photosynthetic system consists of four components: the light source (419 nm), photosensitizer (ZnPP-Mb or $\left.\mathrm{ZnPE}_{1}-\mathrm{Mb}\right)$, substrate $\left(\mathrm{NADP}^{+}\right)$and the sacrificial electron donor (triethanolamine, TEA). We first evaluate the effects of photoirradiation time, dark time, and the sacrificial electron donors on photo-chemical energy conversion efficiency (Supplementary Material: Fig. S2). When the light was omitted from the reaction, no absorbance at $340 \mathrm{~nm}$, assigned to $\mathrm{NADP}^{+}$reduction, could be detected, indicating the light dependence of the reduction of $\mathrm{NADP}^{+}$. Upon photoirradiation, the absorbance at 340 $\mathrm{nm}$ increased along with the decrease and blue shift of the Soret band of $\mathrm{ZnPP}-\mathrm{Mb}$ from 428 to $413 \mathrm{~nm}$ and of $\mathrm{ZnPE}-\mathrm{Mb}$ from $443 \mathrm{~nm}$ to $426 \mathrm{~nm}$, respectively (Fig. $3)$. Furthermore, the absorbance at $340 \mathrm{~nm}$ increased with time even in the dark. We have previously determined the stability of the ZnPP-Mb complex under femtosecond laser irradiation and found that the $a b-$ sorbance at the maxima of both $\mathrm{B}$ and $\mathrm{Q}$ bands decreased with increasing duration of excitation and increasing width of the absorption bands [31]. The $\mathrm{ZnPP}-\mathrm{Mb}$ complexes first absorbed the excitation photons and then relaxed to their lower electronic states via non-radiative transitions, which transfers the excitation energy into the internal energy of the protein. Subsequently, the internal energy of the system might be further transferred into the environment by solvent-induced vibrational relaxation that increases the thermal energy (or temperature) of the local environment. Next, dissociation of the ZnPP-Mb complex might occur under two different circumstances: (1) if dissociation was more rapid than the energy transfer or (2) if dissipation of the thermal energy was too slow. In either situation, the $\mathrm{ZnPP}-\mathrm{Mb}$ complex decomposed so that $\mathrm{ZnPP}$ moved out of the heme pocket of the protein to form aggregates with other free ZnPP species. Therefore, the decrease of Soret band absorbance could be attributed to the conformational change of protein structure and re- 
lease of $\mathrm{ZnPP}$ out of the protein active site pocket, further supporting the essential roles of light in triggering the reaction and affecting the stability of the photosensitizer [31]. After photoirradiation, approximately $90.0 \%$ and $44.6 \%$ of $\mathrm{NADP}^{+}$was photochemically reduced by $\mathrm{ZnPE}_{1}-\mathrm{Mb}$ and $\mathrm{ZnPP}-\mathrm{Mb}$, respectively. Further, when $\mathrm{ZnPE}_{1}-\mathrm{Mb} / \mathrm{TEA}$ was first photoirradiated for $6 \mathrm{hrs}$ before adding the $\mathrm{NADP}^{+}$and kept in the dark for 5 days, reduction of $\mathrm{NADP}^{+}$occurred with similar efficiency as that of simultaneously adding all components at the beginning.
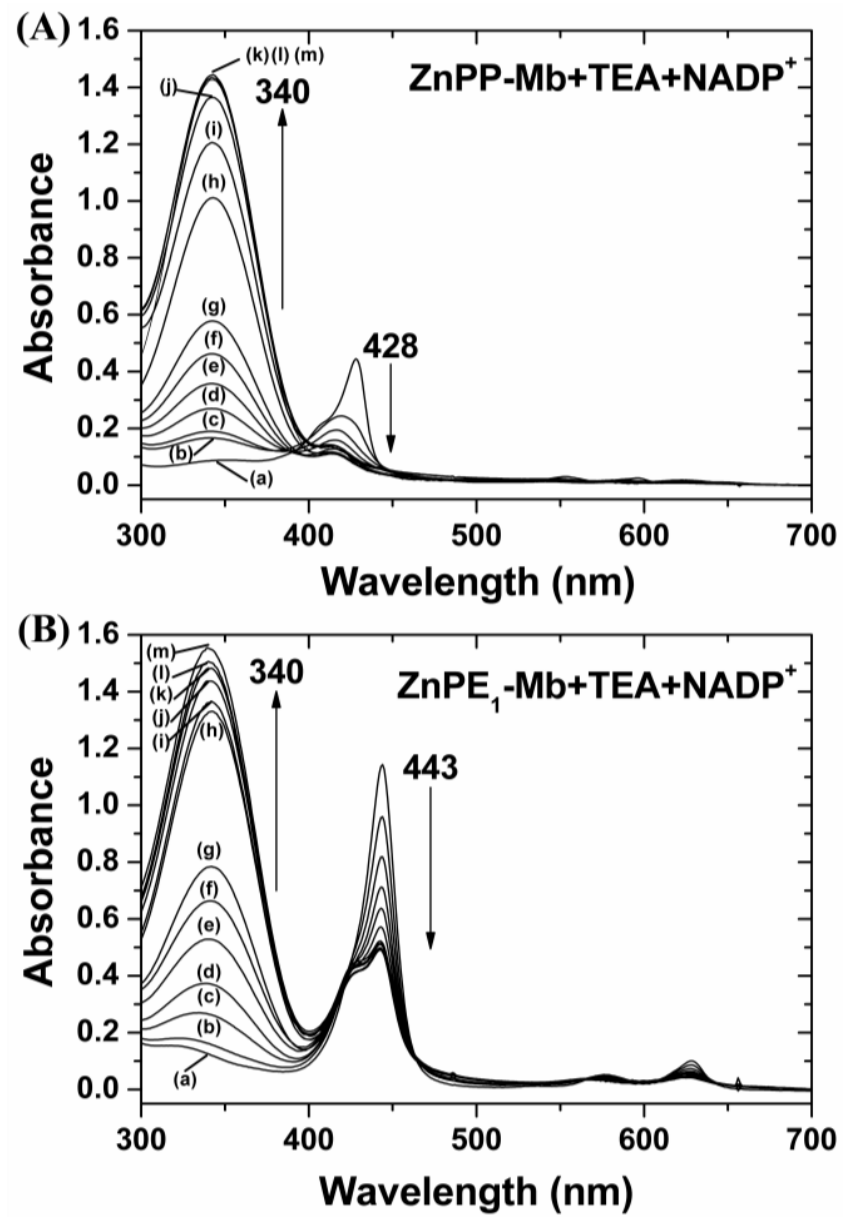

Fig. 3. Change of UV-vis absorption spectra for (A) ZnPP-Mb and (B) ZnPE - Mb co-incubated with TEA and $\mathrm{NADP}^{+}$at different times of photoirradiation and then kept in the dark for up to 5 days. [ZnPP-Mb] $=25 \mu \mathrm{M}$, $\left[\mathrm{ZnPE}_{1}-\mathrm{Mb}\right]=25 \mu \mathrm{M},[\mathrm{TEA}]=\mathrm{I} \mathrm{M},\left[\mathrm{NADP}^{+}\right]=2.5 \mathrm{mM}$. (a) Before irradiation. (b) - (g) Irradiation time was I, 2, 3, 4, 5, and $6 \mathrm{~h}$, respectively. $(\mathrm{h})-(\mathrm{m})$ Irradiation time was $6 \mathrm{~h}$ and then kept in the dark for $12,24,48,72,96,120 \mathrm{~h}$, respectively.

Finally, the highest light-chemical energy conversion efficiency was obtained with optimal concentrations, which contained $1 \mathrm{M}$ TEA, $5 \mathrm{mM} \mathrm{NADP}^{+}$in
$100 \mathrm{mM} \mathrm{KPi}(\mathrm{pH} 9.0$ ), $10 \mu \mathrm{M}$ ZnPE $-\mathrm{Mb}$ (or $25 \mu \mathrm{M}$ $\mathrm{ZnPP}-\mathrm{Mb}$ ), photoirradiation for 6 hours, and was then kept in the dark for 5 days. These results indicated that the $\mathrm{NADP}^{+}$was reduced photochemically following photoirradiation of the solution, consistent with the results previously reported by Nishiyama et al $[33,34]$.

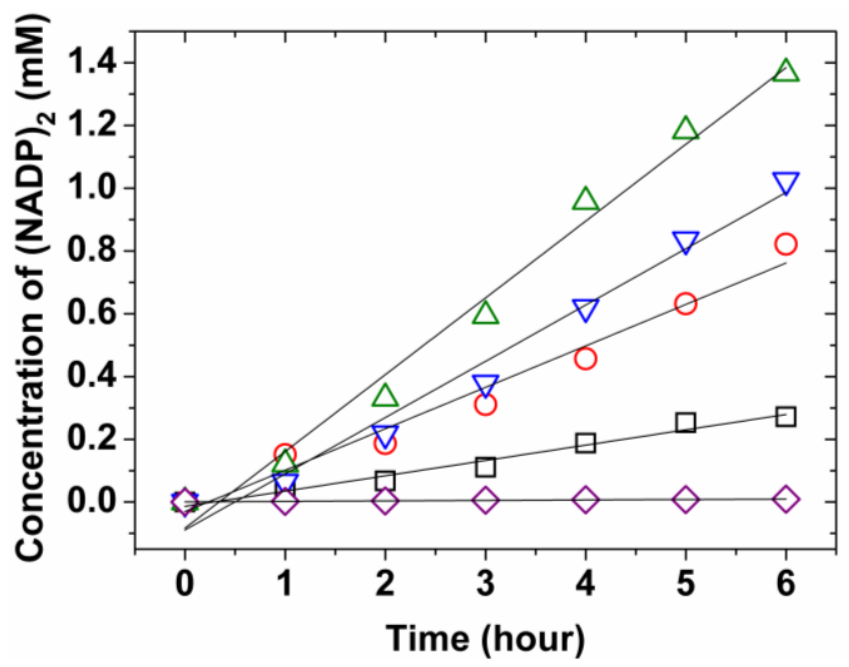

Fig. 4. Effect of protein concentration for catalytic kinetics at photoirradiation. $2.5 \mathrm{mM} \mathrm{NADP}{ }^{+}$with I M TEA were independently reacted with $25 \mu \mathrm{M}$ (O, red) of ZnPP-Mb, 10 $\mu \mathrm{M}$ ( $\square$, black) of ZnPP-Mb, $25 \mu \mathrm{M}$ ( $\nabla$, blue) of ZnPE $-M b$, or $10 \mu \mathrm{M}\left(\Delta\right.$, green) of $\mathrm{ZnPE}_{1}-\mathrm{Mb}$ under photoirradiation in $100 \mathrm{mM} \mathrm{KPi}, \mathrm{pH}$ 9. $2.5 \mathrm{mM} \mathrm{NADP}{ }^{+}$with I M TEA reacted without reconstituted $\mathrm{Mb}(\diamond$, purple) was used as control.

Next, we compared the effect of protein concentrations on the catalytic velocity of $\mathrm{ZnPP}-\mathrm{Mb}$ and $\mathrm{ZnPE}_{1}-\mathrm{Mb}$, respectively. Figure 4 shows the comparison of catalytic velocity for 10 and $25 \mu \mathrm{M}$ of $\mathrm{ZnPP}-\mathrm{Mb}$ or $\mathrm{ZnPE}_{1}-\mathrm{Mb}$, respectively, co-incubated with TEA and $\mathrm{NADP}^{+}$under photoirradiation for $6 \mathrm{hrs}$. The arithmetically catalytic velocity of 10 and $25 \mu \mathrm{M}$ $\mathrm{ZnPP}-\mathrm{Mb}$ is 0.08 and $0.125 \mathrm{mM} / \mathrm{hr}$, whereas that of the 10 and $25 \mu \mathrm{M} \mathrm{ZnPE}-\mathrm{Mb}$ is 0.245 and 0.223 $\mathrm{mM} / \mathrm{hr}$, respectively. No apparent reactivity could be detected for $5 \mathrm{mM} \mathrm{NADP}^{+}$and/or $1 \mathrm{M}$ TEA reacted with apoMb. Interestingly, the catalytic velocity of $\mathrm{ZnPP}-\mathrm{Mb}$ increased with higher ZnPP-Mb concentration, whereas a decline of catalytic velocity was observed in higher $\mathrm{ZnPE}_{1}-\mathrm{Mb}$ concentration. Moreover, an approximately two-fold catalytic velocity for $\mathrm{ZnPE}-\mathrm{Mb}$ is consistent with the photo-chemical energy conversion efficiency. The higher catalytic velocity of $\mathrm{ZnPE}_{1}-\mathrm{Mb}$ than that of $\mathrm{ZnPP}-\mathrm{Mb}$ could be attributed to the higher efficiency of $\mathrm{ZnPE}_{1}$, since measurements of the UV-vis spectra showed that 
$\mathrm{ZnPE}_{1}$ exhibited similar catalytic velocity and conversion efficiency to that of the ZnPP even with lower solubility of $\mathrm{ZnPE}_{1}$ than $\mathrm{ZnPP}$ in KPi buffer. The reconstitution of $\mathrm{ZnPE}_{1}$ into the heme pocket of apoMb prevents aggregation and influences the relaxation of $\mathrm{ZnPE}_{1}$, further improving the energy conversion efficiency [31]. Furthermore, the higher catalytic velocity of $\mathrm{ZnPE}_{1}-\mathrm{Mb}$ at lower concentrations suggested that the equilibrium between the quench of the excited intermediates and the proceeding of the photochemical conversion was reached at a lower concentration for $\mathrm{ZnPE}_{1}-\mathrm{Mb}$ than for $\mathrm{ZnPP}-\mathrm{Mb}$, since similar phenomenon was also observed when the concentration of $\mathrm{ZnPP}-\mathrm{Mb}$ was increased from 25 to $40 \mu \mathrm{M}$ (data not shown).

In parallel, a well-known water soluble porphyrin, 5,10,15,20-tetrakis(1-methylpyridinium-4-yl) porphinatozinc(II) tetrachloride $\left(\mathrm{ZnTMPyP}^{4+}\right)$, was used as a control model in comparison of catalytic velocity with that of $\mathrm{ZnPP}$ and $\mathrm{ZnPE}_{1}$ (Fig. 1). The $\mathrm{ZnTMPyP}^{4+}$ has been used as a photosensitizer and applied in photochemical electron transfer studies $[36,37]$. When $25 \mu \mathrm{M}$ of $\mathrm{ZnPP}, \mathrm{ZnPE}_{1}$, and $\mathrm{ZnTMPyP}^{4+}$ were independently photoirradiated, a catalytic velocity of $0.08,0.111$, and $0.06 \mathrm{mM} / \mathrm{hr}$ were obtained. The results are consistent with the observation that the conversion efficiency of photoinduced NADP+ reduction for $\mathrm{ZnPE}_{1}$ is higher than $\mathrm{ZnPP}$ and $\mathrm{ZnTMPyP}^{4+}$. Furthermore, reconstitution of $\mathrm{ZnPP}$ or $\mathrm{ZnPE}_{1}$ into apoMb improves the conversion efficiency of photoinduced $\mathrm{NADP}^{+}$reduction. These results suggest the protein's possible functional role in preventing quenching aggregation and extending the lifetime for charge separation, both necessary for conversion efficiency improvement. Therefore, the conversion efficiency of photoinduced $\mathrm{NADP}^{+}$reduction in $\mathrm{ZnPP}$ or $\mathrm{ZnPE}_{1}$ is better than that of water soluble ZnTMPyP4+.

\section{Electron transfer mechanism of artificial pho- tosynthetic system}

The reduction of $\mathrm{NADP}^{+}$can occur either by two successive one-electron transfer to form 4,4-(NADP) $)_{2}$ and $4,6-(\mathrm{NADP})_{2}$, or by a single-step transfer of two-electrons and one hydride to form enzymatically active $1,4-\mathrm{NAD}(\mathrm{P}) \mathrm{H}$ or inactive $1,6-\mathrm{NAD}(\mathrm{P}) \mathrm{H}$ [38-41]. Either case can cause an increase of absorbance at 340 $\mathrm{nm}$. To elucidate the $\mathrm{ZnPP}-\mathrm{Mb}$ or $\mathrm{ZnPE}-\mathrm{Mb}$ photoirradiated reaction pathway and product identity, we performed enzymatic analysis using alcohol dehydrogenase, which catalyzes the two-electron conversion of acetaldehyde to ethanol when NADPH is present, and cytochrome $c$, which acts as a single-electron acceptor to reduce ferricytochrome $c$ into ferrocytochrome $c$ [38-41]. Figure 5A shows the absorbance change of NADPH upon enzymatic reactions. Unexpectedly, when alcohol dehydrogenase was incubated with the photoirradiated product, no apparent decrease of absorbance at $340 \mathrm{~nm}$ was observed. In contrast, when the photoirradiated product was added to cytochrome $c$, a characteristic change of $\mathrm{Q}$ band from its oxidized form at $530 \mathrm{~nm}$ into reduced form at 523 and $550 \mathrm{~nm}$ was observed (Fig. 5B) [42]. These results indicated that the product upon photoirradiation may be a (NADP) $)_{2}$ dimer but not an enzymatically active NADPH monomer.
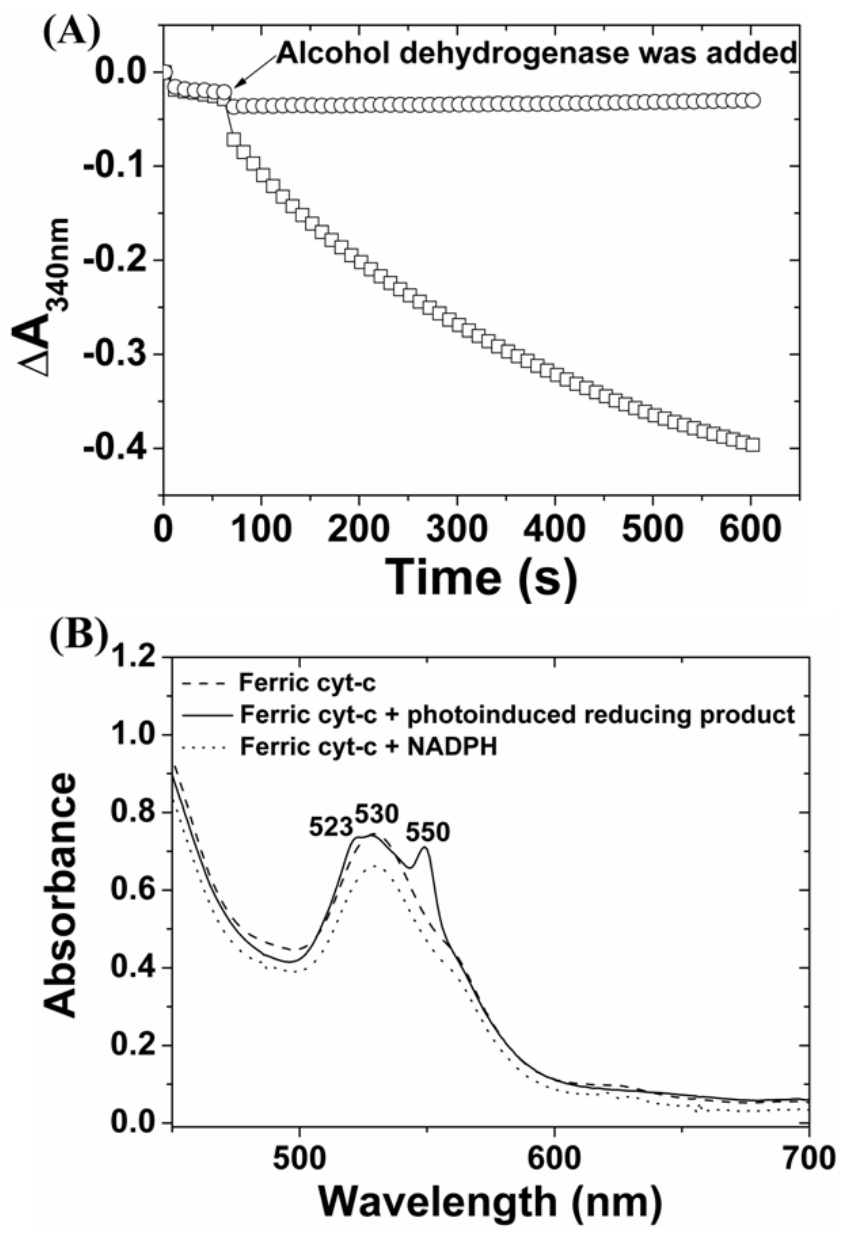

Fig. 5. The enzymatic analysis of NADPH ( $\square$ ) or photoinduced reducing product $(O)$ reacted with $(A)$ alcohol dehydrogenase and acetaldehyde and (B) cytochrome c, respectively.

\section{Photo-induced reduction or oxidation of arti- ficial photosynthetic system}

The $\mathrm{NAD}(\mathrm{P})^{+}$and its reduced form $\mathrm{NAD}(\mathrm{P}) \mathrm{H}$ play critical roles in biological systems. In addition, 
Moore et al. recently constructed a photoelectrochemical biofuel cell which incorporates aspects of both enzymatic biofuel cell and dye-sensitized solar cells [9,43-46]. When the porphyrin-sensitized $n$-type semiconductor photoanode was photoirradiated to induce charge separation, the porphyrin radical cation could be reduced by $\mathrm{NAD}(\mathrm{P}) \mathrm{H}$, which transfers two electrons to the photoanode and generates $\operatorname{NAD}(\mathrm{P})^{+}$ as substrate for subsequent hydrogenase enzyme oxidation. Based on the abovementioned information, we also attempted to characterize whether NADH could be oxidized by $\mathrm{ZnPP}-\mathrm{Mb}$ (or $\mathrm{ZnPE}_{1}-\mathrm{Mb}$ ) under photoirradiation and its potential in constructing a self-regenerative photo-chemical energy conversion system. For the photo-induced oxidation reaction, the reaction buffer was changed from KPi to HEPES to avoid the formation of adduct between the phosphate ion and the pyridine ring of NADH and the subsequent NADH decomposition $[47,48]$. Figure 6 shows the UV-vis spectra change of ZnPP-Mb + NADH, $\mathrm{ZnPP}-\mathrm{Mb}+\mathrm{NADH}+\mathrm{TEA}, \mathrm{ZnPE}_{1}-\mathrm{Mb}+\mathrm{NADH}$, $\mathrm{ZnPE}-\mathrm{Mb}+\mathrm{NADH}+\mathrm{TEA}, \mathrm{NADH}$ and $\mathrm{NADH}+$ TEA in $20 \mathrm{mM}$ HEPES ( $\mathrm{pH}$ 8.5) under continued photoirradiation or dark for 36 hours. As expected, no apparent absorbance change at $340 \mathrm{~nm}$ was detected for NADH and NADH + TEA under photoirradiation. Similar results were obtained when all the above-mentioned reactions were performed under dark reactions for 36 hours. Photoirradiation of $\mathrm{ZnPP}-\mathrm{Mb}+\mathrm{NADH}$ and $\mathrm{ZnPE}-\mathrm{Mb}+\mathrm{NADH}$ resulted in a rapid decrease of absorbance at $340 \mathrm{~nm}$, with a steeper decline for the latter one. These results indicate the light-dependent NADH oxidation reaction in the $\mathrm{ZnPP}-\mathrm{Mb}$ and $\mathrm{ZnPE}_{1}-\mathrm{Mb}$ complex. Next, results of photoirradiation of $\mathrm{ZnPP}-\mathrm{Mb}+\mathrm{NADH}+\mathrm{TEA}$ showed that absorbance at $340 \mathrm{~nm}$ initially decreased but reversely increased after approximately 2 hours. In contrast, when $\mathrm{ZnPE}_{1}-\mathrm{Mb}+\mathrm{NADH}+\mathrm{TEA}$ complex was photoirradiated, its absorbance at $340 \mathrm{~nm}$ decreased rapidly for the first 2 hours and then leveled slightly thereafter. Moreover, the absorbance decay at $340 \mathrm{~nm}$ was slower for $\mathrm{ZnPE}-\mathrm{Mb}+\mathrm{NADH}+\mathrm{TEA}$ than for ZnPP-Mb + NADH + TEA. Finally, the absorbance at $340 \mathrm{~nm}$ reached approximately half of the original intensity for both the ZnPP-Mb + NADH + TEA and the ZnPE $1-\mathrm{Mb}+\mathrm{NADH}+\mathrm{TEA}$ after photoirradiation for 36 hours. Furthermore, detailed comparison of the Soret band decay between $\mathrm{ZnPP}-\mathrm{Mb}$ (or $\mathrm{ZnPE}_{1}-\mathrm{Mb}$ ) with and without TEA showed that the presence of TEA in the reaction solution causes blue-shift and a decrease of the Soret band whereas no shift was observed in the absence of TEA (Supplementary Material: Fig. S3).

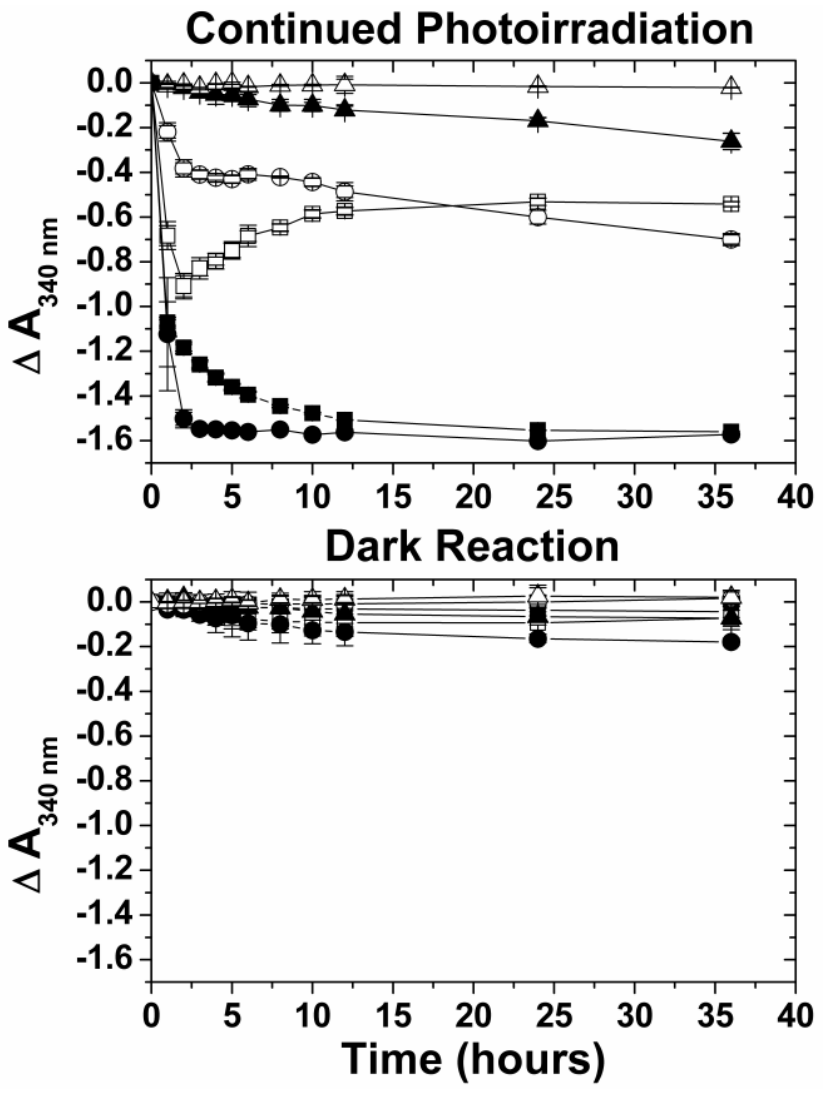

Fig. 6. Summary of the absorbance change at $340 \mathrm{~nm}$ for $\mathrm{ZnPP}-\mathrm{Mb}+\mathrm{NADH}(\mathbf{\square}), \mathrm{ZnPP}-\mathrm{Mb}+\mathrm{NADH}+\mathrm{TEA}(\square)$, $\mathrm{ZnPE}_{1}-\mathrm{Mb}+\mathrm{NADH}(\bullet), \mathrm{ZnPE}_{1}-\mathrm{Mb}+\mathrm{NADH}+\mathrm{TEA}(\mathrm{O})$, $\mathrm{NADH}(\boldsymbol{\Delta})$, and $\mathrm{NADH}+\operatorname{TEA}(\Delta)$ by comparing with continued photoirradiation for 36 hours and dark reaction. $[\mathrm{ZnPP}-\mathrm{Mb}]=25 \mu \mathrm{M},\left[\mathrm{ZnPE}_{1}-\mathrm{Mb}\right]=25 \mu \mathrm{M}$, and $[\mathrm{TEA}]=\mathrm{I} \mathrm{M}$ and $[\mathrm{NADH}]=2.5 \mathrm{mM}$. All in $20 \mathrm{mM}$ HEPES $(\mathrm{pH} 8.5)$.

The results shown in figure 6 indicate that there are two modes of action, the initial oxidation of $\mathrm{NADH}$ to $\mathrm{NAD}^{+}$and the subsequent reduction of $\mathrm{NAD}^{+}$to (NAD) $)_{2}$, for the net absorbance change detected at $340 \mathrm{~nm}$. The absorbance profile difference between $\mathrm{ZnPP}-\mathrm{Mb}+\mathrm{NADH}$ and $\mathrm{ZnPP}-\mathrm{Mb}+\mathrm{NADH}$ + TEA as well as $\mathrm{ZnPE}-\mathrm{Mb}+\mathrm{NADH}$ and $\mathrm{ZnPE}_{1}-\mathrm{Mb}$ $+\mathrm{NADH}+\mathrm{TEA}$ suggest that NADH undergoes initial oxidation to form $\mathrm{NAD}^{+}$, which in the presence of TEA is reduced to form (NAD) $)_{2}$ dimers. This in turn causes the accumulation of (NAD) 2 dimers and partially contribute to the increase of absorbance at 340 $\mathrm{nm}$. Notably, both NADH and (NAD) $)_{2}$ dimer have similar molar absorption coefficients, 6200 and 6400 $\mathrm{M}^{-1} \cdot \mathrm{cm}^{-1}$, respectively $[40,49]$. Thus, in both systems one unit of absorbance is decreased with the consumption of two NADH to generate one (NAD) 2 dimer. Interestingly, the net absorbance profile for the $\mathrm{ZnPP}-\mathrm{Mb}+\mathrm{NADH}+\mathrm{TEA}$ system first decreased to less than half of the total absorbance after 2 hours of 
photoirradiation and then inversely increased to approximately half of the total absorbance after continued photoirradiation for 36 hours. On the other hand, the net absorbance profile of $\mathrm{ZnPE}_{1}-\mathrm{Mb}+\mathrm{NADH}+$ TEA system showed a gentle decline of the $340 \mathrm{~nm}$ absorbance to approximately half of its total value with prolonged reaction time. The discrepancy on the absorbance profile between both systems may be attributed to the stronger inhibitory effect of the TEA for $\mathrm{ZnPE}_{1}-\mathrm{Mb}$ than for $\mathrm{ZnPP}-\mathrm{Mb}$ on the oxidation rate. Consistent with the hypothesis is the observation that both the oxidation rate and the absorbance profile of $\mathrm{ZnPE}_{1}-\mathrm{Mb}$ system is TEA concentration dependent which at lower TEA concentration the oxidation rate increased and the absorbance profile converted from that of the $\mathrm{ZnPE}_{1}-\mathrm{Mb}$ type into that of the $\mathrm{ZnPP}-\mathrm{Mb}$ type (Supplementary Material: Fig. S4).

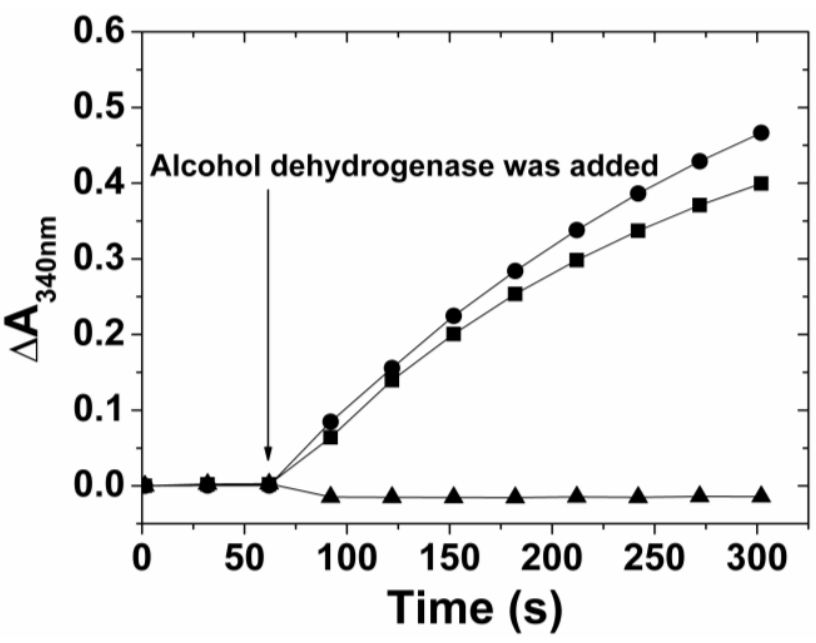

Fig. 7. The enzymatic analysis of alcohol dehydrogenase-catalyzed ethanol oxidation, in the presence of NAD ${ }^{+}$ $(\bullet)$, photoirradiated reactant $(\boldsymbol{\Delta})$, and photoirradiated product $(\mathbf{\square})$. Ethanol and $\mathrm{NAD}^{+}$reactant were co-incubated for 60 seconds before adding the enzyme and the absorbance change at $340 \mathrm{~nm}$ was recorded for every 30 seconds with a total detection time of 5 mins.

To confirm the identity of the $\mathrm{NAD}^{+}$produced by the photoirradiation of $\mathrm{ZnPP}-\mathrm{Mb}$ or $\mathrm{ZnPE} \mathrm{E}_{1}-\mathrm{Mb}$ in the absence of TEA, enzymatic oxidation using alcohol dehydrogenase and ethanol as enzyme and substrate, respectively, was performed. Alcohol dehydrogenase can catalyze reversible oxidoredox reactions of ethanol and acetaldehyde, depending on the added $\mathrm{NAD}^{+}$or NADH in the solution, respectively. When ethanol was oxidized to acetaldehyde, the electron was used to reduce $\mathrm{NAD}^{+}$into $\mathrm{NADH}$, thus leading to the absorbance increase at $340 \mathrm{~nm}$. Figure 7 shows the comparison of the absorbance change at
$340 \mathrm{~nm}$ when $\mathrm{NAD}^{+}$, photoirradiated reactant, and photoirradiated product were used as cofactors for the alcohol dehydrogenase-catalyzed ethanol oxidation. As expected, no absorbance was observed for the photoirradiated reactant on alcohol dehydrogenase-catalyzed oxidation reactions, suggesting that $\mathrm{NADH}$ cannot be used in ethanol oxidation. On the other hand, the absorbance rate at $340 \mathrm{~nm}$ gradually increased when $\mathrm{NAD}^{+}$or photoirradiated product was added to the alcohol dehydrogenase-catalyzed oxidation reaction. These results demonstrate the feasibility of $\mathrm{ZnPP}-\mathrm{Mb}$ or $\mathrm{ZnPE}_{1}-\mathrm{Mb}$ as photoexcited photosensitizers to oxidize NADH and its potential applications in engineering hybrid photoelectrochemical cells.

\section{Hypothetical reaction mechanism of photo- chemical catalysis of ZnPP-Mb/ZnPE,-Mb-based artificial photo- synthetic system for light-chemical energy conversion}

The possible reaction mechanism of photo-induced reduction of $\mathrm{NADP}^{+}$or oxidation of $\mathrm{NADH}$ by $\mathrm{ZnPP}-\mathrm{Mb}$ (or $\mathrm{ZnPE1}-\mathrm{Mb}$ ), in the presence or absence of sacrificial electron donor, respectively, is shown in Scheme 1/Fig. 8. Upon photoirradiation, the absorption of light by the photosensitizer gives rise to an excited state of the $\mathrm{ZnPP}-\mathrm{Mb}^{*}$ (or $\mathrm{ZnPE}-\mathrm{Mb}^{*}$ ), which is subsequently reduced by a sacrificial electron donor such as TEA, thus generating a long-lived $\mathrm{ZnPP}-\mathrm{Mb}^{--}$(or $\mathrm{ZnPE}_{1}-\mathrm{Mb}^{--}$) radical anion [50-56]. A marked absorption around $700 \mathrm{~nm}$, which is characteristic of anion radical formation, was determined by photoirradiation of $\mathrm{ZnPE}_{1}-\mathrm{Mb}$. The analogous formation of zinc cytochrome $c$ anion radical, upon photoirradiation, has been determined by Shen and Kostić, thus supporting the hypothesis [54]. In parallel, a similar reductive photoredox cycle that uses a tin(IV)- or antimony(V)-porphyrin photosensitizer was also previously reported by Shelnutt and Trudell [51]. Furthermore, Maldotti et al. also reported the utilization of photoexcited iron porphyrin to mimic the catalytic activity of cytochrome P-450 oxygenases both in the reduction of halogenated alkanes and in the oxidation of hydrocarbons [55]. Alternatively, in the absence of the TEA, electron transfer from NADH to $\mathrm{ZnPP}-\mathrm{Mb}^{*}$ (or $\mathrm{ZnPE} \mathrm{E}_{1}-\mathrm{Mb}^{*}$ ) may occur to produce the radical ion pair, $\mathrm{NADH}^{+}{ }^{+} \mathrm{ZnPP}-\mathrm{Mb}^{-}$. Consistent with the observation is the reported photo-oxidation of the NADH model compound, 9,10-dihydro-10-methylacridine $\left(\mathrm{AcrH}_{2}\right)$, in the presence of a sensitizer under visible-light irradiation in $\mathrm{MeCN}$ and $\mathrm{H}_{2} \mathrm{O}$ [50]. For photoinduced reduction of $\mathrm{NADP}^{+}$, following photoinduced charge separation, 
the resulting anion radical is oxidized by $\mathrm{NADP}^{+}$in the aqueous solution, ultimately generating (NADP) ${ }_{2}$ dimer. After reduction of the $\mathrm{NADP}^{+}$or oxidation of $\mathrm{NADH}$, the photosensitizer radical anion returns to the resting redox state $\left(\mathrm{ZnPP}-\mathrm{Mb}\right.$ or $\left.\mathrm{ZnPE} \mathrm{E}_{1}-\mathrm{Mb}\right)$. For photoinduced oxidation, the back transfer of an electron from the $\mathrm{ZnPP}-\mathrm{Mb} \cdot-$ anion radical to the NADH*+ is prevented by the trapping of the radical $\mathrm{ZnPP}-\mathrm{Mb}$-(or $\mathrm{ZnPE}-\mathrm{Mb}^{--}$) by oxygen to produce $\mathrm{HO}_{2}$, and subsequently accompanied by regeneration of $\mathrm{ZnPP}-\mathrm{Mb}$ (or $\mathrm{ZnPE}-\mathrm{Mb}$ ). Consistent with the observation is the oxygen dependence of the photo-induced oxidation reaction to generate $\mathrm{H}_{2} \mathrm{O}_{2}$ (Supplementary Material: Figure S5) [50].

In conclusion, we have constructed a bifunctional photo-induced oxidoredox system which, upon photoirradiation, can transfer electrons from $\mathrm{NAD}(\mathrm{P}) \mathrm{H}$ or to $\mathrm{NAD}(\mathrm{P})^{+}$depending on the presence or absence of sacrificial electron donor. The $\mathrm{ZnPP}-\mathrm{Mb}$ or $\mathrm{ZnPE}_{1}-\mathrm{Mb}$ protein pocket can prevent the quenching aggregate and extend the lifetime of charge separation. In addition, the efficiency of the $\mathrm{NADP}^{+}$reduction using $\mathrm{ZnPE}_{1}-\mathrm{Mb}$ is approximately two-fold greater than that of the system using $\mathrm{ZnPP}-\mathrm{Mb}$. In parallel, the $\mathrm{ZnPP}-\mathrm{Mb}$ or $\mathrm{ZnPE}-\mathrm{Mb}$ artificial photosynthetic system carried out a step-to-step one electron transfer mechanism upon photo-induced charge transfer. Finally, the $\mathrm{ZnPP}-\mathrm{Mb} / \mathrm{ZnPE}_{1}-\mathrm{Mb}$ artificial photosynthetic system can be realized as a potential bio-photosentizer and applied for the development of renewable energy to replace our reliance on fossil fuels.

\section{Photoinduced oxidation reaction Photoinduced reduction reaction}

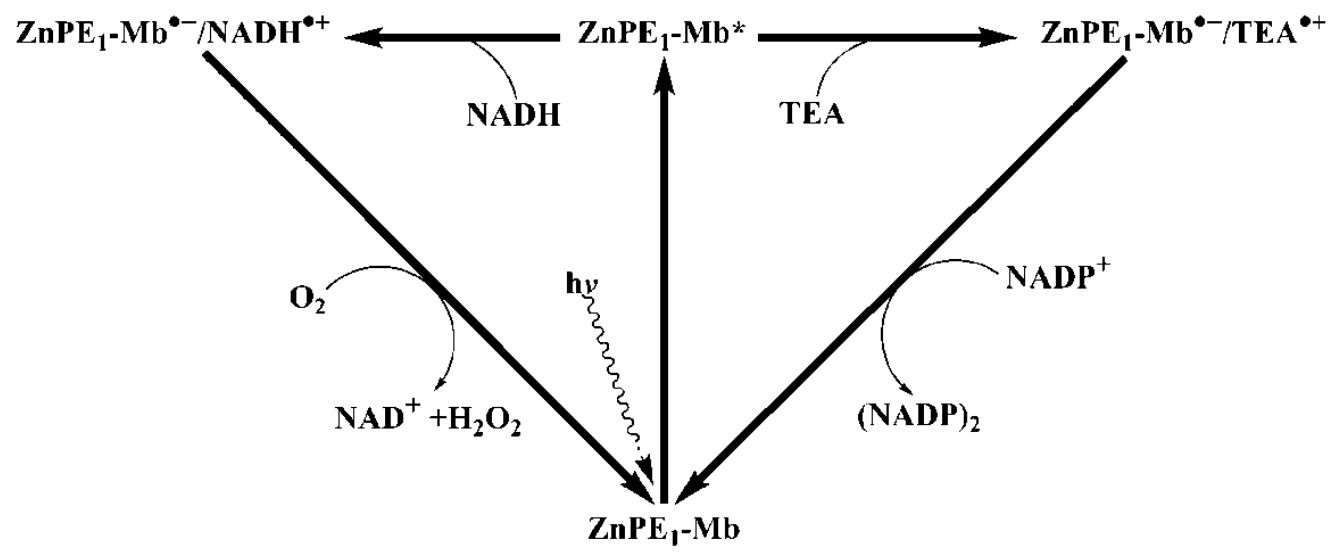

Fig.8. (Scheme I) Schematic representation of photochemical catalysis of $\mathrm{ZnPE}_{1}-\mathrm{Mb}$-based artificial photosynthetic system for light-chemical energy conversion.

\section{Materials and methods}

\section{Preparation of reconstituted ZnPP-Mb and ZnPE - -Mb}

Apomyoglobin was prepared by the modified butanone method of heme extraction, as previously described [35]. The reconstitution of $\mathrm{ZnPP}$ or $\mathrm{ZnPE}_{1}$ into $\mathrm{apoMb}$ was performed according to the modified method of Axup et al [57]. Briefly, the apo-protein solution was maintained at ice bath for the duration of the reconstitution process. A 1.5-fold molar excess of $\mathrm{ZnPP}$ (or $\mathrm{ZnPE}_{1}$ ) in DMSO was added dropwise to a $10 \mathrm{mM} \mathrm{KPi} / \mathrm{DMSO}(4: 1 \mathrm{v} / \mathrm{v})$ buffer containing apomyolobin at $\mathrm{pH}$ 12. After incubation for $15 \mathrm{~min}$, the solution was adjusted to $\mathrm{pH} 7.0$ and allowed to stir for $6 \mathrm{hr}$ at $4{ }^{\circ} \mathrm{C}$. The solution was transferred to a dialysis bag against phosphate buffer $(10 \mathrm{mM} \mathrm{KPi}$ buffer $\mathrm{pH}$ 6.8 ) overnight. The protein solution was filtered with $0.45 \mu \mathrm{m}$ cellulose membrane before applied to a Sephadex G-25 column. The column was equilibrated with $100 \mathrm{mM} \mathrm{KPi}$ buffer $\mathrm{pH} 6.8$, and eluted with the same buffer at $4{ }^{\circ} \mathrm{C}$. The protein was passed through the column, collected and stored at $-20{ }^{\circ} \mathrm{C}$ for later experiments.

\section{Photo-induced reduction experiments}

The UV-vis absorption spectra were recorded with a standard spectrometer (HP 8453); emission spectra were measured with a fluorescence spectrometer (Hitachi F-700). Photoirradiation reactions were carried out in a photochemical reactor PR-2000 (PANCHUM, Kaohsiung, Taiwan) at room temperature $\left(25^{\circ} \mathrm{C}\right)$ using two RPR $4190 \AA$ A lamps that show an 
emission maximum at $419 \pm 15 \mathrm{~nm}$ at half bandwidth. The light intensity at the cell is $6 \mathrm{~mW} / \mathrm{cm}^{2}$. For photoreduction reaction, photoirradiation was carried out in a final volume of $1 \mathrm{~mL}$ of $100 \mathrm{mM}$ phosphate buffer (pH 9.0) containing $25 \mu \mathrm{M}$ ZnPP-Mb (or $10 \mu \mathrm{M}$ $\left.\mathrm{ZnPE}_{1}-\mathrm{Mb}\right), 2.5 \mathrm{mM}$ of $\mathrm{NADP}^{+}$, and $1 \mathrm{M}$ TEA. For photo-induced reduction reaction, the change in the absorbance at $340 \mathrm{~nm}$ was detected at 1, 2, 3, 4, 5, 6, 18, $30,54,78,102$, and $126 \mathrm{~h}$.

\section{Photo-induced oxidation experiments}

For photo-induced oxidation reaction, $25 \mu \mathrm{M}$ of $\mathrm{ZnPP}-\mathrm{Mb}$ or $\mathrm{ZnPE}-\mathrm{Mb}$ and $2.5 \mathrm{mM} \mathrm{NADH}$ were used, but TEA was omitted from the reaction solution. The reaction solution was photoirradiated at $419 \mathrm{~nm}$ for $6 \mathrm{hrs}$ and the change in the absorbance at $340 \mathrm{~nm}$, which attributed to (NADP) $)_{2}$ or $\mathrm{NAD}^{+}$formation, was recorded. The equipment of photo-induced oxidation experiments is the same as that of the photo-induced reduction experiments. For photo-induced oxidation reaction, the absorbance was detected at $1,2,3,4,5,6$, $8,10,12,24$ and $36 \mathrm{~h}$.

\section{Enzymatic product characterization of pho- to-induced reduction reactions}

The general procedure of $\mathrm{NAD}(\mathrm{P}) \mathrm{H}$ enzymatic assay was determined spectrophotometrically using a modified method of Hanson and Jacobson [58]. $10 \mu \mathrm{L}$ of acetaldehyde was pre-mixed with $\mathrm{NADPH}$ or photoinduced reducing product in $1 \mathrm{ml}$ cuvette. $10 \mu \mathrm{L}$ of $10 \mathrm{U} \mathrm{mL} \mathrm{mL}^{-1}$ alcohol dehydrogenase was added to the mixture and rapidly mixed. As the enzyme catalyzed acetaldehyde to ethanol, the change of absorbance at $340 \mathrm{~nm}$ was monitored for 10 mins. For a single-electron acceptor, cytochrome c, which shows absorption maxima of $Q$ band at $530 \mathrm{~nm}$ in the oxidized form and at 523 and $550 \mathrm{~nm}$ in the reduced form, was used [59]. $25 \mu \mathrm{M}$ of cytochrome c was converted into the fully oxidized form by autoxidation for 30 min at $\mathrm{pH} 3$ at $20^{\circ} \mathrm{C}$, then mixed with NADPH or photoinduced reducing product for 10 mins, respectively [60]. The spectra change of cytochrome c reduction reaction was recorded. All changes of UV-vis spectra were recorded by a standard spectrometer (HP 8453).

\section{Enzymatic product characterization of pho- to-induced oxidation reactions}

The enzymatic assay of photo-induced oxidation product was similar with that of photo-induced reduction product but the substrate and coenzyme were replaced with ethanol and $\mathrm{NAD}^{+}$or photoinduced oxidation product. The change of absorbance at 340 nm was also monitored. All changes of UV-vis spectra were recorded by a standard spectrometer (HP 8453).

\section{Acknowledgements}

The authors gratefully acknowledge financial support from National Chiao Tung University, MOE ATU Plan, and National Science Council (NSC-98-2627-M-009-007 and NSC-98-2627-M-009008).

\section{Abbreviations}

$\mathrm{ZnPP}-\mathrm{Mb}$ : zinc-protoporphyrin myoglobin; ZnPE1-Mb: 5-(4-carboxy-phenylethynyl)-10,20biphenyl porphinato zinc (II) myoglobin; ATP: adenosine triphosphate; NADPH: nicotinamide adenine dinucleotide phosphate; apoMb: apomyoglobin.

\section{Supplementary Material}

Fig.S1-S7. http://www.biolsci.org/v07p1203s1.pdf

\section{Conflict of Interests}

The authors have declared that no conflict of interest exists.

\section{References}

1. Zhou JS, Granda ESV, Leontis NB, and Rodgers MAJ. Photoinduced electron transfer in self-associated complexes of several uroporphyrins and cytochrome c. J. Am. Chem. Soc. 1990; 112: 5074-5080

2. McLendon $G$, and Hake R. Interprotein electron transfer. Chem. Rev. 1992; 92: 481-490

3. Chang CW, Chang CH, Lu HP, Wu TK, and Diau EW. Fabrication and photovoltaic characterization of bio-sensitized solar cells using myoglobin-based sensitizers. J. Nanosci. Nanotechnol. 2009; 9: 1688-1695

4. Long YT, Sutherland TC, Kraatz HB, and Lee JS. Photoinduced production of $\mathrm{NAD}(\mathrm{P}) \mathrm{H}$ from an activated fluorescein-DNA monolayer. Chem. Commun. 2004; 18: 2032-2033

5. Komatsu T, Wang RM, Zunszain PA, Curry S, and Tsuchida E. Photosensitized reduction of water to hydrogen using human serum albumin complexed with zinc-protoporphyrin IX. J. Am. Chem. Soc. 2006; 128: 16297-16301

6. Matsuo T, Asano A, Ando T, Hisaeda Y, and Hayashi T. Photocatalytic hydrogen generation using a protein-coated photosensitizer with anionic patches and a monocationic electron mediator. Chem. Commun. 2008; 31: 3684-3686

7. Hagfeldt A, and Grätzel M. Molecular photovoltaics. Acc. Chem. Res. 2000; 33: 269-277

8. Grätzel M. Dye-sensitized solar cells. J. Photochem. Photobiol. 2003; 4: 145-153

9. Grätzel M. Conversion of sunlight to electric power by nanocrystalline dye-sensitized solar cells. J. Photochem. Photobiol. 2004; 164: 3-14

10. Grätzel M. Solar energy conversion by dye-sensitized photovoltaic cells. Inorg. Chem. 2005; 44: 6841-6851

11. Martı́nez-Díaz MV, and Torres T. Handbook of Porphyrin Science; Volume 10. Singapore: Academic Press. 2010

12. Bottari G, de la Torre G, Guldi DM, and Torres T. Covalent and noncovalent phthalocyanine-carbon nanostructure systems: 
synthesis, photoinduced electron transfer, and application to molecular photovoltaics. Chem. Rev. 2010; 110: 6768-6816

13. Bessho T, Zakeeruddin SM, Yeh CY, Diau EWG, and Grätzel M. Highly efficient mesoscopic dye-sensitized solar cells based on donor-acceptor-substituted porphyrins. Angew. Chem. Int. Ed. 2010; 49: 6646-6649

14. Rang YJ, and Spikes JD. The porphyrin-sensitized photooxidation of horseradish apoperoxidase. Arch. Biochem. Biophys. 1976; 172: 565-573

15. Bellelli A, Brzezinski P, Arese M, Cutruzzola F, Silvestrini MC, and Brunori M. Electron transfer in zinc-reconstituted nitrite reductase from Pseudomonas aeruginosa. Biochem. J. 1996; 319: 407-410

16. Crnogorac MM, and Kostic NM. Redox reactivity and reorganization energy of zinc cytochrome c cation radical. Inorg. Chem. 2000; 39: 5028-5035

17. Hitomi Y, Hayashi T, Wada K, Mizutani TY, Hisaeda Y, and Ogoshi $\mathrm{H}$. Interprotein electron transfer reaction regulated by an artificial interface. Angew. Chem. Int. Ed. 2001; 40: 1098-1101

18. Liang ZX, Nocek JM, Huang K, Hayes RT, Kurnikov IV, Beratan DN, and Hoffman BM. Dynamic docking and electron transfer between Zn-myoglobin and cytochrome b. J. Am. Chem. Soc. 2002; 124: 6849-6859

19. Hu YZ, Tsukiji S, Shinkai S, Oishi S, and Hamachi I. Construction of artificial photosynthetic reaction centers on a protein surface: vectorial, multistep, and proton-coupled electron transfer for long-lived charge separation. J. Am. Chem. Soc. 2000; 122: 241-253

20. Tsukahara K, Kimura C, and Sakurai T. Intracomplex quenching by copper(II) ion of excited singlet and triplet states of zinc myoglobin modified with diethylenetriaminepentaacetic acid. Chem. Lett. 1997; 26: 601-602

21. Murakami H, Matsumoto R, Okusa Y, Sagara T, Fujitsuka M, Ito $\mathrm{O}$, and Nakashima N. Design, synthesis and photophysical properties of C60-modified proteins. J. Mater. Chem. 2002; 12: 2026-2033

22. Hay S, Wallace BB, Smith TA, Ghiggino KP, and Wydrzynski T. Protein engineering of cytochrome b562 for quinone binding and light-induced electron transfer. Proc. Natl. Acad. Sci. U. S. A. $2004 ; 101: 17675-17680$

23. Harriman A. Luminescence of porphyrins and metalloporphyrins. J. Chem. Soc. Farady I 1980; 76: 1978-1985

24. Barboy N, and Feitelson J. Quenching of the zinc-protoporphyrin triplet state as a measure of small-molecule diffusion through the structure of myoglobin. Biochemistry 1987; 26: 3240-3244

25. Albani J, and Albert B. Fluctuation domains in myoglobin. Fluorescence quenching studies. Eur. J. Biochem. 1987; 162: $175-178$

26. Ilari A, Boffi A, and Chiancone E. Rigidity of the heme pocket in the cooperative Scapharca hemoglobin homodimer and relation to the direct communication between hemes. Arch. Biochem. Biophys. 1995; 316: 378-384

27. Aono S, Nemoto S, Ohtaka A, and Okura I. Photoreduction of cytochrome $\mathrm{c}$ with zinc protoporphyrin reconstituted myoglobin (ZnPP-Mb). J. Mol. Catal. A: Chem. 1995; 95: 193-196

28. Polm MW, and Schaafsma TJ. Triplet state magnetic resonance and fluorescence spectroscopy of metal-substituted hemoglobins. Biophys. J. 1997; 72: 373-382

29. Yu HZ, Baskin JS, and Zewail AH. Ultrafast dynamics of porphyrins in the condensed phase: II; zinc tetraphenylporphyrin. J. Phys. Chem. A 2002; 106: 9845-9854

30. Hu YZ, Takashima H, Tsukiji S, Shinkai S, Nagamune T, Oishi $\mathrm{S}$, and Hamachi I. Direct comparison of electron transfer properties of two distinct semisynthetic triads with non-protein based triad: unambiguous experimental evidences on protein matrix effects. Chem. Eur. J. 2000; 6: 1907-1916
31. Luo L, Chang CH, Chen YC, Wu TK, and Diau EWG. Ultrafast relaxation of zinc protoporphyrin encapsulated within apomyoglobin in buffer solutions. J. Phys. Chem. B. 2007; 111: 7656-7664

32. Luo L, Lin CJ, Tsai CY, Lu HP, Li LL, Lo CF, Lin CY, and Diau EWG. Effects of aggregation and electron injection on photovoltaic performance of porphyrin-based solar cells with oligo(phenylethynyl) links inside $\mathrm{TiO}_{2}$ and $\mathrm{Al}_{2} \mathrm{O}_{3}$ nanotube arrays. Phys. Chem. Chem. Phys. 2010; 12: 1064-1071

33. Nishiyama K, Uchiyama M, Mie Y, and Taniguchi I. Photochemical reduction of $\mathrm{NADP}^{+}$by zinc protoporphyrin reconstituted myoglobin as a simple model of photosystem I. Chem. Lett. 1999; 28: 357-358

34. Nishiyama K, Mie Y, Kishita M, Yamada C, Kitagawa R, and Taniguchi I. Phototriggered chemical reduction of $\mathrm{NADP}^{+}$by zinc-reconstituted myoglobin and triethanolamine as a sacrificial donor. Chem. Lett. 2005; 34: 1032-1033

35. Teale FW. Cleavage of the haem-protein link by acid. Biochim. Biophys. Acta 1959; 35: 543

36. Houlding VH, Kalyanasundaram K, Grätzel M, and Milgrom LR. Kinetics of triplet decay of water soluble porphyrins. Analysis of ionic strength effects. J Phys Chem. 1983; 87: 3175-3179

37. Kalyanasundaram K, and Neumann-Spallart M. Photophysical and redox properties of water-soluble porphyrins in aqueous media. J. Phys. Chem. 1982; 86: 5163-5169

38. Burnett RW, and Underwood AL. A dimer of diphosphopyridine nucleotide. Biochemistry 1968; 7: 3328-3333

39. Jensen MA, and Elving PJ. Nicotinamide adenine dinucleotide $\left(\mathrm{NAD}^{+}\right)$. Formal potential of the $\mathrm{NAD}^{+} / \mathrm{NADH}$ couple and NAD dimerization rate. Biochim Biophys Acta. 1984; 764: 310-315

40. Avigliano L, Carelli V, Casini A, Finazzi-Agrò A, and Liberatore F. Oxidation of NAD dimer by horseradish peroxidase. Biochem. J. 1985; 226: 391-395

41. Avigliano L, Carelli V, Casini A, Finazzi-Agrò A, Liberatore F, and Rossi A. Oxidation of nicotinamide coenzyme dimers by one-electron-accepting proteins. Biochem. J. 1986; 237: 919-922

42. Koike H, and Katoh S. Heat-stabilities of cytochromes and ferredoxin isolated from a thermophilic blue-green alga. Plant Cell Physiol. 1979; 20: 1157-1161

43. Garza LDL, Jeong G, Liddell PA, Sotomura T, Moore TA, Moore AL, and Gust D. Enzyme-based photoelectrochemical biofuel cell. J. Phys. Chem. B. 2003; 107: 10252-10260

44. Brune A, Jeong G, Liddell PA, Sotomura T, Moore TA, Moore $\mathrm{AL}$, and Gust D. Porphyrin-sensitized nanoparticulate $\mathrm{TiO}_{2}$ as the photoanode of a hybrid photoelectrochemical biofuel cell. Langmuir 2004; 20: 8366-8371

45. Hambourger M, Brune A, Dust G, Moore AL, and Moore TA. Enzyme-assisted reforming of glucose to hydrogen in a photoelectrochemical cell. Photochem. Photobiol. 2005; 81: 1015-1020

46. Hambourger M, Gervaldo M, Svedruzic D, King PW, Dust G, Ghirardi M, Moore AL, and Moore TA. [FeFe]-hydrogenase-catalyzed $\mathrm{H}_{2}$ production in a photoelectrochemical biofuel cell. J. Am. Chem. Soc. 2008; 130: 2015-2022

47. Wu JT, Wu LH, and Knight JA. Stability of NADPH: effect of various factors on the kinetics of degradation. Clin. Chem. 1986; 32: 314-319

48. Rover JL, Fernandes JC, de Oliveira Neto G, Kubota LT, Katekawa E, and Serrano SH. Study of NADH stability using ultraviolet-visible spectrophotometric analysis and factorial design. Anal. Biochem. 1998; 260: 50-55

49. Carelli V, Liberatore F, Casini A, Mondelli R, Arnone A, Carelli I, Rotilio G, and Mavelli I. Dimers of nicotinamide adenine dinucleotide: New evidence for the structure and the involvement in an enzymatic redox process. Bioorg. Chem. 1980; 9: 342-351 
50. Fukuzumi S, Ishikawa M, and Tanaka T. Mechanisms of photo-oxidation of NADH model compounds by oxygen. J. Chem. Soc. Perkin Trans. II, 1989;: 1037-1045

51. Shelnutt JA, and Trudell DE. Photochemical-driven biomimetic oxidation of alkanes and olefins; Volume 437. US: Am Chem Soc. 1990;

52. Golovin NM, Seymour P, Jayaraj K, Fu Y, and Lever ABP. Perchlorinated phthalocyanines: spectroscopic properties and surface electrochemistry. Inorg. Chem. 1990; 29: 1719-1727

53. Mack J, and Stillman MJ. Photochemical formation of the anion radical of zinc phthalocyanine and analysis of the absorption and magnetic circular dichroism spectral data. Assignment of the optical spectrum of $[\mathrm{ZnPc}(-3)]$. J Am Chem Soc. 1994; 116: 1292-1304

54. Shen C, and Kostić NM. Reductive quenching of the triplet state of zinc cytochrome c by the hexacyanoferrate(II) anion and by conjugate bases of ethylenediaminetetraacetic acid. Inorg. Chem. 1996; 35: 2780-2784

55. Maldotti A, Andreotti L, Molinari A, and Carassiti V. Photochemically driven models of oxygenases based on the use of iron porphyrins. J. Biol. Inorg. Chem. 1999; 4: 154-161

56. Sinyakov GN, Shul'ga AM, Filatov IV, and Dzilinsky K. The electronic structure of transient species in the photochemical reduction of porphyrins. High Energy Chem. 2002; 36: 255-259

57. Axup AW, Albin M, Mayo SL, Crutchley RJ, and Gray HB. Distance dependence of photoinduced long-range electron transfer in Zinc/Ruthenium-modified myoglobins. J. Am. Chem. Soc. 1988; 110: 435-439

58. Hanson A, and Brown A. Three alcohol dehydrogenase genes in wild and cultivated barley: characterization of the products of variant alleles. Biochem. Genet. 1984; 22: 495-515

59. Margoliash E, and Frohwirt N. Spectrum of horse-heart cytochrome c. Biochem. J. 1959; 71: 570-572

60. Brady RS, and Flatmark T. Autoreduction of horse heart ferricytochrome c. Kinetic and equilibrium studies of the over-all reaction. J. Mol. Biol. 1971; 57: 529-539 